\title{
MLL/SEPT5 Fusion Protein
}

National Cancer Institute

\section{Source}

National Cancer Institute. MLLISEPT5 Fusion Protein. NCI Thesaurus. Code C99334.

A fusion protein encoded by the MLL/SEPT 5 fusion gene. This protein is comprised of the $\mathrm{N}$-terminal half of the histone-lysine $\mathrm{N}$-methyltransferase MLL protein, including the AT hook DNA binding domain and the DNA methyltransferase domain, fused with the Cterminus of the septin- 5 protein. 